\title{
Toward negotiated mitigation of landslide risks in informal settlements: reflections from a pilot experience in Medellín, Colombia
}

\author{
$\underline{\text { Harry Smith }}^{1}$, Françoise Coupé $^{2}, \underline{\text { Soledad Garcia-Ferrari }}^{3}, \underline{\text { Helena Rivera }}^{4}$ and $_{\text {Wilmar Edgardo Castro Mera }^{2}}$
}

\begin{abstract}
Urbanization continues to drive informal settlement growth on land exposed to hazards such as landslides, increasing risk among low-income populations. Though technical and social ways of managing landslide risk are known, in developing countries these measures are often difficult to implement because of complex social, economic, political, and institutional reasons. We present the findings from a pilot research project in Medellín, Colombia, which aimed to explore the scope for, and acceptability of, landslide risk-reducing strategies for informal settlements from the community and state perspectives; understand the barriers to landslide riskreducing strategies; and identify politically and practically viable approaches to such strategies within a wider and more complex context of social and physical risk in the area. Focusing on the latter objective, we compare two forms of community-local government spaces for negotiation that were used during the project (a Cabildo Abierto and a joint local government-community Working Group), applying Fung's "democratic cube" to their analysis. This helps understand their different nature, but also raises questions about the ability of Fung's model to address governance arrangements related to so-called informal settlements in the Global South, and the need to revisit this model drawing on context-sensitive approaches and insights on informal governance arrangements from the growing literature on service coproduction. The key conclusions highlight the importance of overcoming the state-community stand-off over land occupation rights in Medellín, which is also found in self-built neighborhoods worldwide, by reorienting the problem away from conventional longterm land use planning issues toward issues of safety in the short and medium term, together with an incremental approach, in opening up opportunities to develop wider negotiated mitigation of landslide risk at a more strategic level involving both community and local government.
\end{abstract}

Key Words: community self-management; coproduction; informal settlements; land use planning; landslide risk management; Latin America; negotiation

\section{INTRODUCTION}

Urbanization continues to drive informal settlement growth on land exposed to hazards such as landslides, increasing risk among low-income populations. Approaches to reducing hazard, exposure, and vulnerability and improving resilience to landslides include land use plans, good construction practice, warning systems, community preparedness and awareness campaigns, pooling and transferring risk, and physical protection barriers (Nadim and Lacasse 2008). Though technical and social ways of managing landslide risk are known, in cities in the Global South these measures are often difficult to implement because of complex social, economic, political, and institutional reasons, not least of which is low institutional capacity (Abbott 1996, Grindle 1996, Jenkins and Smith 2001). Key issues that impact on the capacity to manage risk include differences in perception of risk among stakeholders, from community to state (UN/ISDR 2004, Wamsler 2007, Maskrey 2011), lack of opportunity for different types of knowledge (informal/formal, technical/social; Chardón 1997, Rivera 2010, Muñoz Duque 2014) to interact in defining risk and risk-mitigation strategies (Blaikie and Cannon 1996, UNGRD 2013), lack of resources (UN-Habitat 2015), and differences in stakeholder agendas and balances of power.

Generally, landslide management risk in informal settlements has tended to be limited to rescue and recovery emergency interventions after an event, or as a preventative measure, the latter often involving evictions (UN-Habitat 2003, 2015). In Medellín, Colombia, the removal of inhabitants based on landslide risk reasons and municipal investment in highly visible public infrastructures on the same site or on sites with apparently similar conditions, has led to distrust of local government among community organizations. This hinders the development of joint landslide risk management strategies that could be shared across local government and different levels of community organization, including mitigation measures that are appropriate to geographic scale and timescale.

We present the findings from an action-research project in Medellín, Colombia, which aimed to explore the scope for, and acceptability of, landslide risk-reducing strategies for informal settlements from the community and state perspectives; understand the barriers to such strategies; and identify politically and practically viable approaches within a wider and more complex context of social and physical risk. We first review the literature on state-community engagement around negotiated mitigation of landslide risk, and briefly explore the relevance of literature on coproduction of urban services, before setting out the research objectives of the action-research project this paper draws on. We describe the physical, social, and institutional context of Medellín's landslide risks, and against this background explain the research strategy and methods applied. We discuss in more depth the process developed during the research focused specifically on developing a joint community-state approach to landslide risk mitigation, initially facilitated by academia, and analyze the results from this process applying Fung's (2006) "democracy cube" and Abbott's (1996) "participation surround." The key conclusions highlight the importance of overcoming the state-community standoff over land occupation rights by

${ }^{1}$ Centre for Environment and Human Settlements, The Urban Institute, Heriot-Watt University, Edinburgh, United Kingdom, ${ }^{2}$ Escuela del Habitat, Facultad de Arquitectura, Universidad Nacional de Colombia Sede Medellín, Medellín, Colombia, ${ }^{3}$ Edinburgh School of Architecture and Landscape Architecture, Edinburgh College of Art, University of Edinburgh, Edinburgh, United Kingdom, ${ }^{4}$ A Small Studio Ltd. | Architecture + Planning Research 
reorienting the problem away from conventional long-term land use planning issues toward issues of safety in the short and medium term, together with an incremental approach, in opening up opportunities to develop wider negotiated mitigation of landslide risk at a more strategic level involving both community and local government. This novel approach and the insights derived from this action-research, which show the need to refine models such as Fung's (2006) "democracy cube" to reflect the complexity of context, are of relevance to informal settlements throughout Latin America and elsewhere and in keeping with the current complexity paradigm for disaster risk reduction (DRR), which builds upon previous purely engineering, behavioral, and developmental paradigms.

\section{Theoretical framework}

The literature on joint community-local government strategies to address landslide risks in informal settlements is very limited. Low perception of risk of disasters in general among vulnerable communities is seen as a two-fold problem of information and cultural factors, with identified solutions including increasing access to information that is good in quantity and quality, and awareness-raising through education and campaigns (UN/ISDR 2004). Research on household coping strategies has highlighted what communities are able to do for themselves when aware of the risks or affected by disaster events (e.g., Wamsler 2007, Maskrey 2011). However, according to Wamsler (2007:VI), there is a "substantial gap between what household and communities need or do to deal with risk and disasters and the way in which urban development actors support them." Maskrey advocated the acknowledgement of disaster risk and appropriate decision making and action by both communities and relevant external actors, suggesting communities need to change their roles from objects to subjects and "persuade government at all levels to participate in communities' own programmes" (2011:44). In this vein, it has been argued that governments should move away from using clearance as the prevailing answer to so-called slums (Neekrhra 2008), and define "'acceptable' levels of vulnerability and anti-seismic standards" with revised implementation of urban guidelines that recognize informal developments and set basic architectural parameters for their growth (Filardi 2008:117). On the other hand, working on landslide risk reduction, Rahman (2012) concluded that informal settlers usually have little willingness to adapt to risk-reduction measures and it is therefore the responsibility of institutions to provide new arrangements, gain community trust, and treat each vulnerable site on a caseby-case basis. Rahman (2012) recommended building partnership among urban government and community-based organizations formed by informal settlement residents to reduce disaster risk.

A rare example of this is the management of slope stability in communities (MoSSaiC) approach to urban landslide hazard mitigation developed in the eastern Caribbean, which brings together politicians, government agencies, and community residents, in conjunction with contractors from the community, in a cycle where stakeholders work together to understand and mitigate localized causes of landslide hazards. The activities in this approach focus on community-based mapping of local slope features, assessing the dominant slope instability drivers, and, where appropriate, building low-cost drainage networks to manage surface water, the latter being designed by the government engineers and constructed by contractors in the community. This approach has built community ownership of the process, by engaging it in the planning, execution, and maintenance of surface water management on high-risk slopes from start to finish (Anderson et al. 2007, Anderson and Holcombe 2013). However, so far MoSSaiC projects have not been implemented in situations where there may be social and political conflicts that hinder partnership, and therefore have not explored the role of negotiation in such situations.

Promoting joint work on disaster mitigation often requires surmounting negative official views of informal settlements, as evidenced by Neekrhra (2008), a challenge that has also been faced for the provision of urban services. In this regard, there is scope to learn from the growing experience in coproduction of such services. Emerging forms of governance around water and sanitation provision involving the articulation of so-called informal and formal systems, and of community and service delivery actors, have been documented around the world (see, e.g., Allen et al. 2006, Phumpiu and Gustaffsson 2009, Batley and Mcloughlin 2010, Olivier de Sardan 2011, Wild et al. 2012). Moretto (2014:217), drawing on evidence elsewhere as well as on research on water services coproduction in Venezuela, concludes that "co-production largely benefitted from informal, tentative, irregular and unofficial relationships between the stakeholders involved in the service delivery" and that "formal governance mechanisms appear to be less influential than the way governance processes work in practice in a rather case-specific and locally-influenced context."

Could these insights from work in service coproduction help find ways forward to address the challenges of landslide risk mitigation in informal settlements? Although they point to the potential of exploring alternative forms of relationship between community and state in doing so, three key issues must also be borne in mind: First, providing safety from landslides is not a traditionally recognized service that a price can be put to, and therefore will not attract the range of service providers that has been documented for water and sanitation, though this could change if awareness of landslide risks and of ways of mitigating this developed; instead it variously falls under the cross-cutting policy categories of climate change adaptation, sustainable development, and disaster risk management that require multiagency/actor coordination. Second, there are different scales at which landslide risk management operates, with different roles being appropriate for the various stakeholders according to scale, from top-down policy makers and planners, often concerned with land use zoning, disaster preparedness, vulnerability reduction, and risk transfer, to site-specific engineering works for hazard mitigation (see again Anderson and Holcombe 2013). And finally, related to the second issue, at the heart of coproduction lies the issue of governance, in particular the decision-making mechanisms and processes of interaction between community and state actors. To understand these we need to turn to the literature on public participation and governance.

A key reference point for any discussion of public participation is Arnstein's (1969) participation ladder, which continues to be widely cited (e.g., Fung 2006, 2012, Brooks and Harris 2008, Ruesga and Knight 2013, Carpentier 2016). However, recent writing tends to be critical of Arnstein's ladder. Fung (2006), for example, acknowledges that it still provides a useful tool for understanding citizen participation but only for those with a "naïve and 
untempered enthusiasm for public participation" (Fung 2006:67), and claims that as an analytical tool it is "obsolete and defective" (Fung 2006:67). The first criticism is that Arnstein merges the idea that individuals should have influence over decision making into an apparently normative approval, whereas sometimes it may be more appropriate for individuals to have a more "consultative role" and not aspire to "full citizen control," which is the top rung of the ladder.

An important advance in the literature on public participation and democratic governance since Arnstein (1969) is Fung's work on the "democratic cube" (2006). This three-dimensional space is mapped out along three axes: (1) participant selection, responding to the question "who participates?"; (2) the communicative mode, which is about how the participants communicate and make decisions; and (3) the extent of influence, which is about the connection between participants' inputs and public policy and action. For each axis, Fung (2006) proposes a range of possibilities. For participant selection, Fung places "expert administrators" at the "more exclusive" end of the spectrum and the diffuse public sphere at the "more inclusive" end. The communicative mode ranges from "listening as a spectator" as the "least intense," to "deploying technique and expertise" as the "most intense," with "deliberating and negotiating" being the second most intense. And for the extent of influence the range goes from "personal benefits" (least authority) to "direct authority" (most authority), with "cogovernance" coming second in terms of most authority.

Fung (2006:74) proposes this as "a framework for thinking about the major design variations in contemporary participatory institutions," with a view to understanding actual cases of citizen participation that advance legitimacy, justice, and effectiveness of public action, rather than applying preconceptions about what participatory democracy should look like. We therefore apply Fung's democratic cube to the analysis of the spaces for negotiation (or for concertación, as will be explained below) established during the action-research project in Pinares de Oriente.

However, there are limitations to Fung's framework, namely that despite its stated aspiration to support a "footloose analytic approach," it establishes categories along its three axes that may not necessarily be comprehensive because they appear to be based mostly on cases in the Global North, and it does not explicitly engage with the context of the participatory experience to be analyzed. A useful way to address this may be to supplement Fung's democracy cube with Abbott's (1996) notion of the "participatory surround." Abbott (1996) provides a conceptual framework to study, practice, and evaluate community participation from the perspective of research undertaken in South Africa. Abbott claims that it would be a conceptual flaw to understand participation as a duality between citizens and authorities, and to imagine there is a single or series of mechanisms for public participation. This happens in "most published work which deals with the theoretical construct of the community participation model" (Abbott 1996:66) because participation processes can be related to either a paradigm approach model or a project-based model of participation. Instead, urban management encompasses a wide and complex range of participatory mechanisms that are fully inter-related as a set of activities, actors, and interests, hence the "participatory surround."

Abbott (1996) argues that it is essential to place community participation within its wider surround before making any attempt at finding the appropriate process for public participation. Whereas one process might be appropriate in one community, a different community will require a separate process because it is operating within a different political, economic, geographic, and social surround. Understanding the participatory surround is thus critical when working within public participation and democratic governance. These reflections underpin the approach piloted in the action-research project this paper draws on, which required an in-depth understanding of the context, i.e., the participatory surround.

\section{Research objectives}

The project's overall aim was met through sequential achievement of three objectives:

- Objective 1 was to understand perceptions and narratives of risk among the different stakeholders, from community to relevant local government organizations, and to explore the implications of these for the adoption of landslide risk mitigation strategies and actions.

- Objective 2 was to test community self-managed landslide risk monitoring and mitigation approaches through pilot action-research projects in a specific informal settlement.

- Objective 3 focused on collaborative identification of mechanisms to reach agreement between informal settlement communities and relevant state agencies in order to develop a sustainable process of risk-mitigation strategy building and implementation.

\section{MATERIAL AND METHODS}

We turn next to explaining the methods underpinning the approach piloted in the action-research project this paper draws on. This approach required an in-depth understanding of the participatory surround, and we therefore start with the context of the city of Medellín.

\section{Area and case study}

Aristizábal and Gómez (2007), drawing on data from Desinventar, report a total of 6750 disaster events between 1880 and 2007 in the Metropolitan Area of the Aburrá Valley (AMVA), which is located between two mountain ranges that are part of the northern Andes. Of these events, 71.8\% happened within the Municipality of Medellín, and 35\% were landslides. In 2012 an estimated 44,600 informal settlement households were at risk of landslides in the Medellín Metropolitan Area, expected to rise by 13,000 more by 2030 (URBAM and Harvard Design School 2012), located mostly in the peri-urban area.

A combined approach to land use planning and management, and risk management, has emerged in Medellín over recent decades as a response to specific events and situations. An early example is the upgrading of Moravia, a centrally located neighborhood inhabited since the 1950 s by internally displaced people as well as other low-income residents (Alcaldía de Medellín 2005), which following its municipal designation as a landfill site was dealt with officially through eviction, thus generating 
Fig. 1. Map of risk zones in Medellín. Source: adapted by the authors from Empresa de Desarrollo Urbano (Urban Development Agency) cartography.

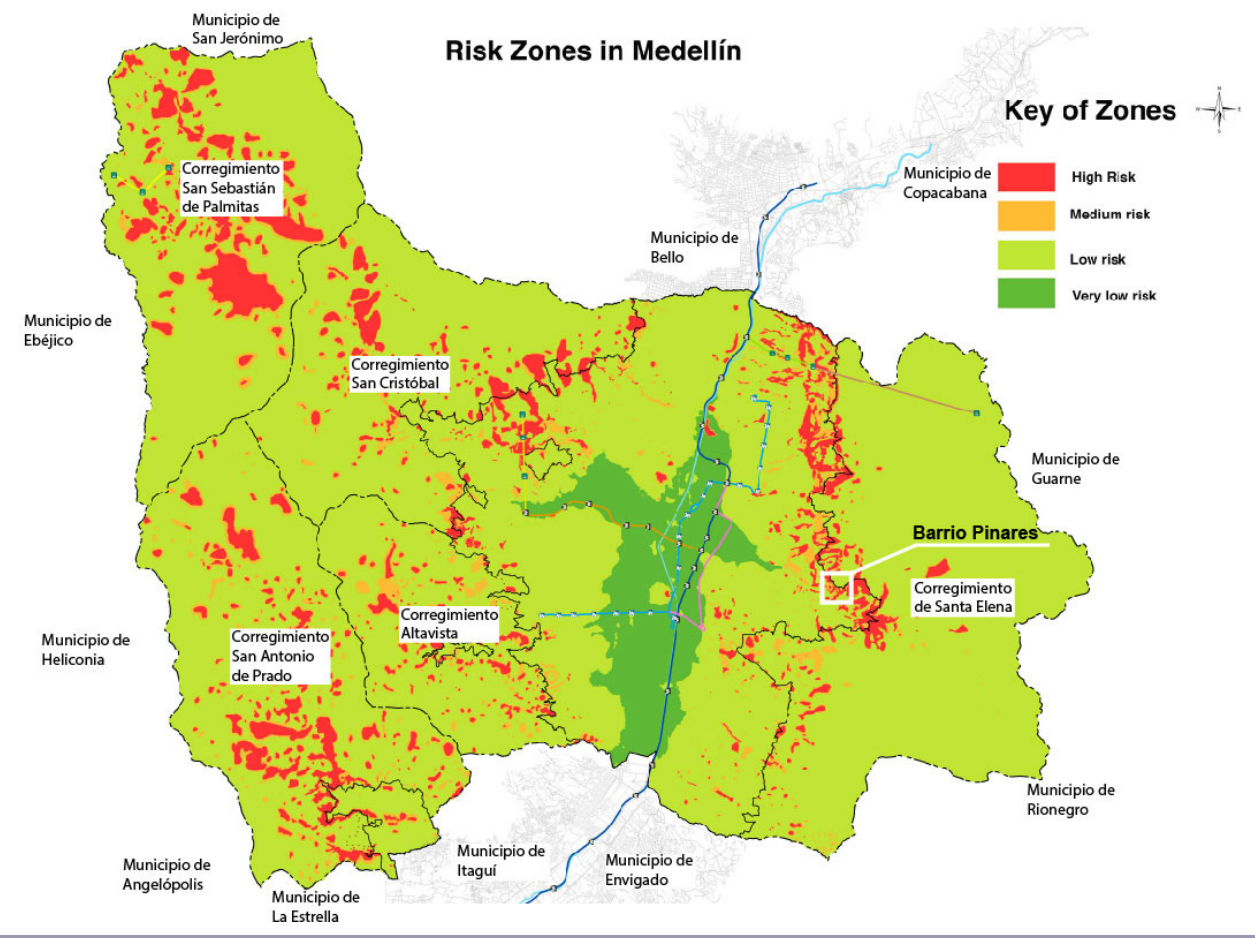

resistance and a fight to stay on site (Sánchez and Gutiérrez 2014). A neighborhood improvement project that started in 1983 with community engagement was partially successful, though some relocated people returned to the neighborhood for its central location, and others struggled to maintain their social and economic networks after relocation. Subsequent neighborhood improvement has resulted in the landfill becoming a garden with a community-run plant-growing business, and a new school and community center.

Another relevant experience was the response to the tragedy caused by a major landslide in 1987 that left approximately 500 dead, 100 dwellings destroyed, and around 2400 people affected in the informal settlement of Villatina (Coupé et al. 2007). This event brought about a change in how risk was conceptualized, raising awareness of threats from outside the neighborhood and of hillsides and ravines as factors affecting the level of risk (Coupé et al. 2007). It was a precedent for the creation of Colombia's national disaster management system (Sistema Nacional de Prevención y Atención de Desastres, SNAPD), and for two types of initiative the Municipality of Medellín started to promote: relocation in new settlements and neighborhood upgrading (Sánchez and Gutiérrez 2014).

Since these early experiences, with the incorporation of risk as a major consideration in the Medellín Land Use Plan (Plan de Ordenamiento Territorial, POT), planning policies have thus become part of risk management, in theory addressing both vulnerability and mitigatable hazards. Their approach is based on the conceptualization of risk as the product of exposure to hazard and vulnerability (Nadim and Lacasse 2008), the former being based on geological and hydrological studies, and the latter taking into account the quality of construction among other factors. The POT defines areas of land as being at risk or at nonmitigatable high risk (Alcaldía de Medellín 2014). Areas that are defined as at mitigatable risk following detailed study are considered as potentially developable and officially eligible for public resources (see Fig. 1). However, many informally produced neighborhoods and parts of neighborhoods have been designated as at nonmitigatable high risk, and the official expectation is that their inhabitants will not remain in these locations in the long-term, with public authority refusal to engage in long-term investment in the areas, even though some utilities may be provided in these areas by other agents. This has led to mobilization and confrontation such as those seen in Moravia in the early 1980s, but on a much larger scale, fostered also by the mixed messages sent by the municipality through its investment in major public infrastructures on land that had been designated as being at high risk.

However, local government in Medellín has attempted to engage communities in risk management. In 2006 the Metropolitan Area of the Aburrá Valley (Área Metropolitana del Valle de Aburrá, AMVA) created a community network for environmental management of land (see Fig. 2), articulated with the Metropolitan Network for Risk Management, and currently formed by a range of community groups: Community Committees for Risk Management (Comités Comunitarios de Gestión del Riesgo, CCGR) within the Municipality of Medellín, and Environmental Committees of the Valley of Aburrá (known as CUIDÁ) in the other nine municipalities in the Metropolitan Area (Toro et al. 2009). The CUIDÁ community organizations 
are more focused on wider environmental education, while the CCGR in Medellín have a stronger emphasis on risk recovery. Currently there are CCGR in every comuna (district) of the city of Medellín, with 112 committees comprising around 1000 people. These committees depend on the municipality's Administrative Department for Disaster Risk Management (Departamento Administrativo de Gestión del Riesgo de Desastres, DAGRD), have low levels of empowerment, and their impact has not been evaluated to date.

Fig. 2. State-led community involvement in disaster risk management in Medellín: the Community Network for Environmental Management. Source: the authors.

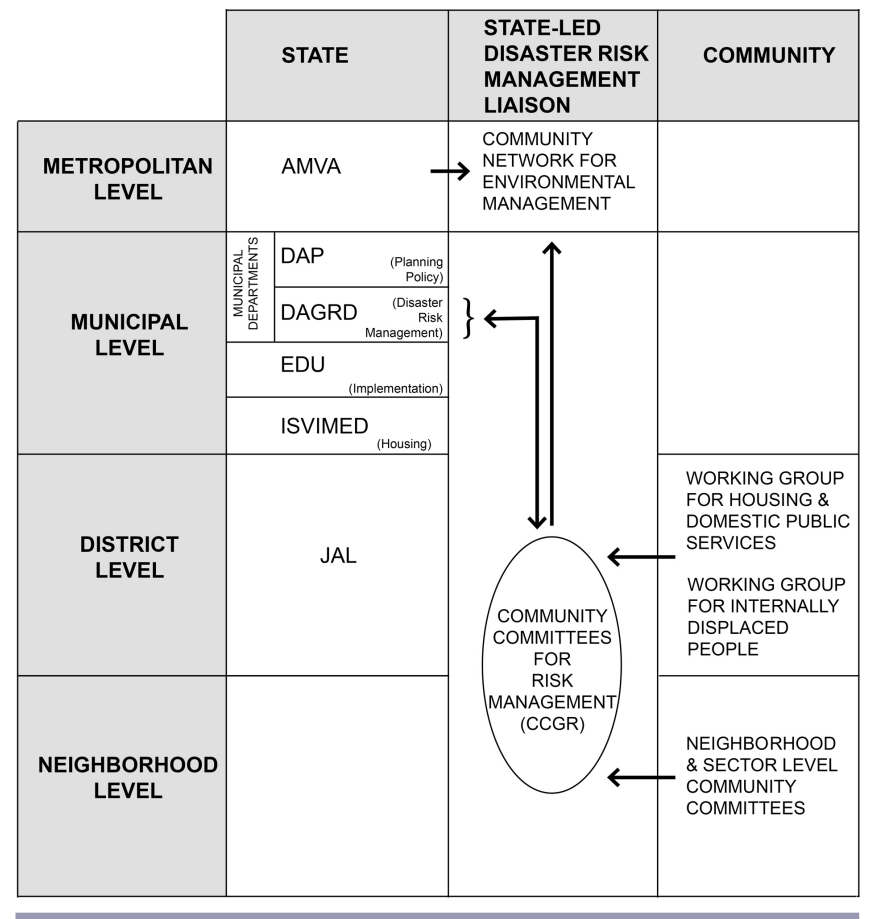

Within the municipal administration, the main relevant actor is DAGRD, charged with identifying disaster risk scenarios and monitoring, as well as with disaster risk mitigation and prevention, focused mostly on emergency attention and recovery, with incipient focus on prevention through the community initiatives. There is scope for preventative action and mitigation in the policy making remit of the municipality's Administrative Department of Planning, as evidenced in the coverage of risk within the POT, while implementation of infrastructures is the responsibility of the Urban Development Agency (Empresa de Desarrollo Urbano, EDU). Within the municipality there is also a role for the Medellín Social Institute of Housing and Habitat (Instituto Social de Vivienda y Hábitat de Medellín, ISVIMED) whenever provision of housing is involved, and beyond the municipality a key actor at the metropolitan level is the AMVA.

Because of the focus that community organizations involved in the formally constituted Community Network for Environmental Management have on education and recovery, and the weak links between this and organizational structures involved in wider land use policies and risk mitigation, other community-based organizations have increasingly taken on these issues. Notable among these are the grassroots community boards that coordinate community action across districts and the city. The project this paper reports on worked in particular with the Board for Internally Displaced People (Mesa de Desplazados) and the Board for Housing and Domestic Public Services (Mesa de Vivienda y Servicios Públicos Domiciliarios) in Comuna 8, the district where the pilot community was located. These community-based district-wide boards have been increasingly vocal in relation to the need to address risk mitigation in addition to other issues such as recognition of informal settlements, land regularization, and titling and neighborhood upgrading.

Against this physical, social, and organizational background, as its main aim this project set out to explore possible ways to bring together the key actors around joint efforts to address landslide risk mitigation, starting from the bottom up, i.e., from the experience of a specific neighborhood. The neighborhood that was chosen as a case study is Pinares de Oriente, a small self-built neighborhood located on steep slopes high above the city center (from 1738 to $1824 \mathrm{~m}$. in altitude, the city center is at approximately $1500 \mathrm{~m}$. above sea level; see Fig. 3). Pinares is in the center-east part of Medellín, situated within the Comuna 8 district of the city. It covers an area of 1.52 ha and is inhabited by 180 households, with approximately 800 residents. Eighty percent have been internally displaced by the over 50-year-long social and armed conflict in Colombia. Medellín has been particularly affected by this conflict, an ongoing consequence being that in peri-urban neighborhoods such as Pinares, land allocation is often in the hands of armed groups that operate outside the law. The neighborhood initially developed between 2000 and 2005 through invasion of municipal land, driven by a member of an armed group.

Fig. 3. View of one of the access lanes in Pinares de Oriente. Source: the authors.

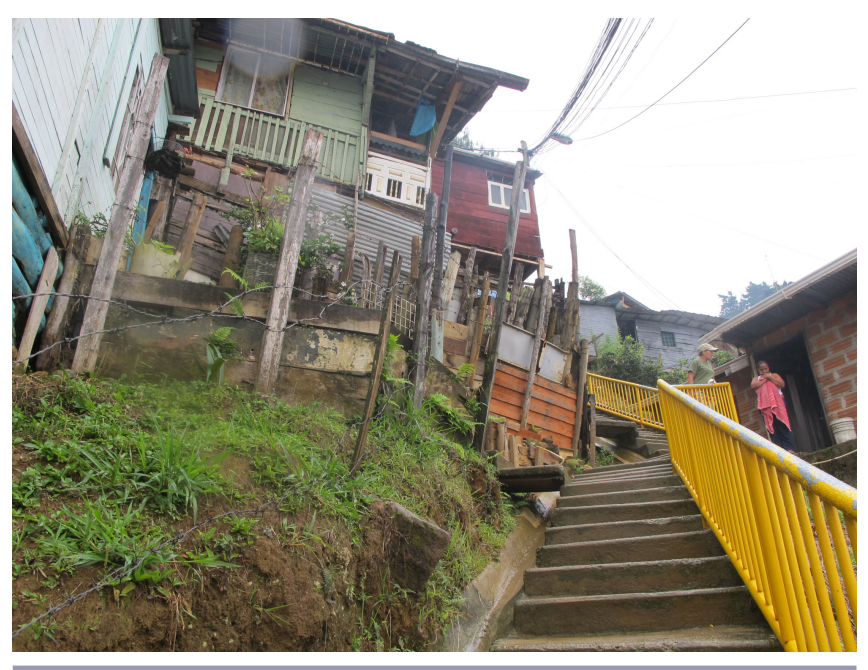

According to the Municipal Land Use Plan (POT), part of the neighborhood of Pinares de Oriente is on land designated for urban expansion subject to comprehensive improvement. The rest is outside the officially designated urban perimeter. A ravine called La Loquita 1 crosses the settlement. It carries water only during 
periods of intense rainfall. The Municipality of Medellín has designated three areas in the neighborhood according to risk levels: low risk, high mitigatable risk, and high nonmitigatable risk (see Fig. 4). The latter is also the area that lies outside the officially designated urban perimeter, home to 70 households, and is the part that the project focused its efforts on. The Comuna 8 district is part of one of the "Strategic Intervention Areas" defined in the POT as presenting opportunities for transformation of the territory to consolidate the model of land occupation pursued in the plan (Alcaldía de Medellín 2014).

Fig. 4. Risk zones in Pinares de Oriente. Source: adapted from Empresa de Desarrollo Urbano and SIGA 2015.

\section{Key of Zones}
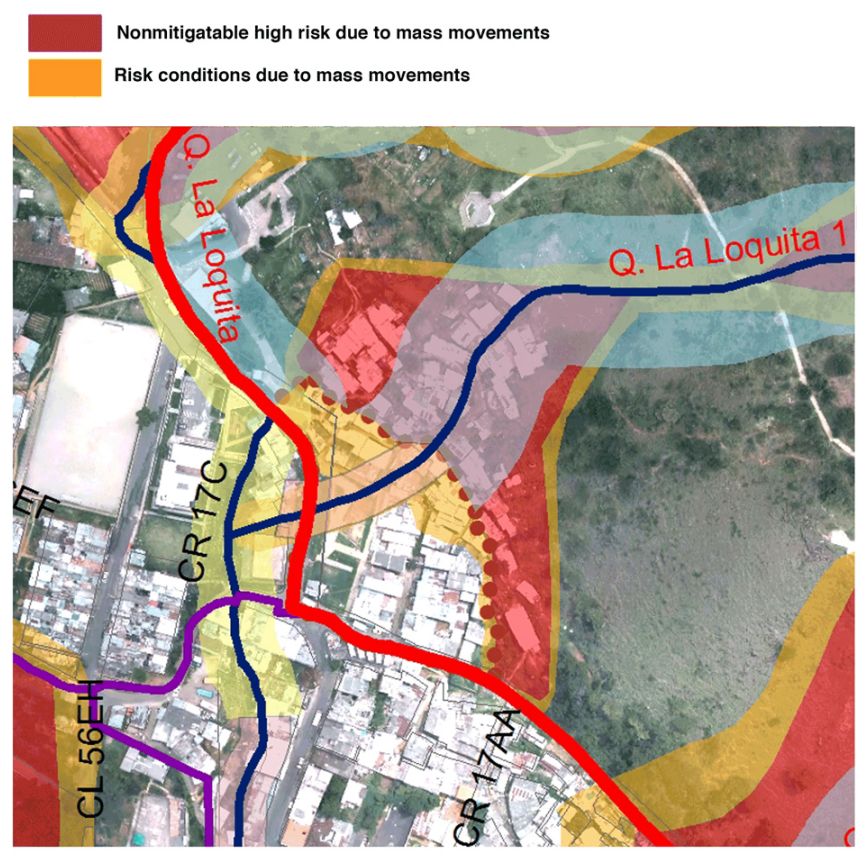

\section{Research strategy}

Each of this action-research project's three objectives was addressed through specific methods. The first objective, to understand perceptions and narratives of risk among the different stakeholders, was met through focus groups and semistructured interviews with community residents and community leaders in the informal settlement of Pinares de Oriente, and semistructured interviews with local government officials with responsibility for this area. The second objective was to test community selfmanaged landslide risk monitoring and mitigation approaches through pilot action-research projects, which were implemented in Pinares de Oriente. The community-based landslide risk monitoring system involved identification of key points in the community that might give early warning of land movement through changes in inclination of vertical elements such as posts, changes in vegetation, etc. Volunteers in the community became community researchers, forming groups that took responsibility for several monitoring points and sent photographs via WhatsApp, providing the geotechnical experts in the academic research team with regularly updated information on ground conditions. The community-based risk mitigation pilot involved a degree of technical assessment of ground conditions and nature of construction in the settlement, which identified appropriate surface water management as a key aspect to address in order to reduce the probability of small landslides occurring within the settlement. The academic team provided technical coordination and materials, with community volunteers providing labor, and a locally based contractor managed the mitigation works. The focus of the works was on providing appropriate drainage and paving in communal areas in between the houses, and gutters, and drainpipes on some houses where this intervention would benefit others as well. Both monitoring and mitigation action-research pilots were evaluated by the community in workshops held at the end of the process.

The final objective of the research project, which is the focus of this paper, explored the collaborative identification of mechanisms to reach agreement between informal settlement communities and relevant state agencies in order to develop a sustainable process of risk-mitigation strategy building and implementation. The residents of Pinares have a Junta de Acción Comunal (JAC, Community Action Board), which is the form of neighborhood-based elected community organization that is prevalent in Colombia, and which in this case helped to recruit the community-based researchers. Each neighborhood-based JAC manages its decision-making processes independently, some being more democratic than others, but in Comuna 8 there is strong collaboration between JACs, which is facilitated by the district-wide community boards mentioned earlier. The pilot project was grounded in action-research together with the community-based researchers in Pinares, but the academic research team considered it was important to pave the way for this collaborative identification of mechanisms to reach agreement from the beginning of the process, and held initial discussions with key actors within the Municipality including the Administrative Department for Planning and DAGRD in January 2017. DAGRD, as an administrative department, is on the same hierarchical level as the planning department within the municipality. However, DAGRD is an executor of plans prepared by the planning department, though their mutual engagement and collaboration is limited, with DAGRD's activities being focused mostly on emergency attention and recovery in a predominantly top-down way. Earlier talks had also been held with the Metropolitan Area of the Aburrá Valley (AMVA), which, as explained, is a key actor at the metropolitan level whose institutional complexity also means the decision-making process is traditional and formal, and dependent on agreement of each of its nine constituent municipal governments. These, together with the interviews held with local government officials to explore their perceptions, served to set out the intentions of the project and were positively received by these organizations. At the request of the community in Pinares, in May and June 2017 one of the academic team members in Colombia delivered two training workshops for Pinares residents and leaders, mostly members of the housing board, as part of a series of training events organized by Corporación Montanoa, an NGO that works with communities. This helped to start preparing the community for its later engagement with local government actors. It included some exploration of the notion of agreement, which in the 
Colombian context was translated as concertación. Mechanisms for concertación covered in the training included conciliation, arbitration, consultation, negotiation, and consensus building.

Later, in August 2017, the academic research team responded to an invitation from the community leadership of Comuna 8, and took part in a Cabildo Abierto, which is a form of public meeting contemplated in Colombian law, whereby local government bodies invited to it are required to attend and to respond to the petitions that the community makes to them, though they are not legally bound by decisions agreed at the meeting (Alvarado Beltrán 2014). Although its use dates back to 1840 , it became a statutory instrument for public participation in 1991 and is considered the primary formal route whereby citizens can communicate with the state (Alvarado Beltrán 2014). A Cabildo Abierto can be convened by a group of residents calling on any of the authorities that manage either a local zone, a district, or a municipal area falling within the residents' jurisdiction. The intention of the Cabildo (as defined in the constitution) is that all residents should have access to decision making, thus "enforcing political control without intermediaries, providing more means of expression and ways of solving [state] conflicts" (Alvarado Beltrán 2014:103). The Cabildo is not only seen as a tool for democratic participation, but importantly, as an opportunity to hold authorities to account (Alvarado Beltrán 2014) with regard to the concerns of residents, though legally it has only a deliberative character. Using Fung's dimensions, it can be seen as "open with self-selection" in terms of participant selection (toward the more inclusive end of the range) and somewhere between "expressing preferences" and "deliberative" in terms of mode of communication (toward the most intense end of the range) but having only "communicative influence" (toward the least influence end of the range) in terms of extent of authority and power (see Table 1).

Table 1. Pinares de Oriente governance spaces mapped using Fung's democratic cube. Source: the authors.

\begin{tabular}{|c|c|c|}
\hline \multirow[t]{2}{*}{ Dimensions } & \multicolumn{2}{|c|}{ Type of governance space } \\
\hline & Cabildo Abierto & Working Group \\
\hline Participant selection & Open self-selection & $\begin{array}{l}\text { (Mediated) open self- } \\
\text { selection }\end{array}$ \\
\hline Communicative mode & $\begin{array}{l}\text { Express preferences / } \\
\text { Aggregation and } \\
\text { bargaining / Deliberate } \\
\text { and negotiate }\end{array}$ & $\begin{array}{l}\text { Deliberate and } \\
\text { negotiate (but also } \\
\text { deploy techniques and } \\
\text { expertise) }\end{array}$ \\
\hline Extent of influence & $\begin{array}{l}\text { Communicative } \\
\text { influence }\end{array}$ & $\begin{array}{l}\text { Advise and consult / } \\
\text { Cogovernance }\end{array}$ \\
\hline
\end{tabular}

The Cabildo was convened by the Comuna 8 Local Administration Board (Junta Administradora Local, JAL), which is the lowest tier of local government, after the lead researcher in the Colombian academic team brokered an agreement between this organization and the district's community boards and JACs to hold such a meeting: the JAL had the legal capacity to demand the municipality's response, whereas the JACs had the outreach to ensure community participation. The Cabildo was held at a municipal sports center on the edge of Pinares, with the theme of "For Risk Mitigation and Comprehensive Legalization," this being the first time a Cabildo had been convened in Medellín to address risk mitigation. It attracted the participation of over 600 people, including residents from across the district and representation from the main relevant municipal departments (see Fig. 5). At the event, following presentations from the academic team members, each neighborhood community committee presented their petitions. Those presented by the Pinares de Oriente community leaders included a request to the Municipality to open a space for dialogue around risk mitigation in the community. The exposition of petitions was followed by a public discussion between key community leaders and local government representatives.

Fig. 5. Cabildo Abierto in Comuna 8, 26 August 2017. Source: the authors.

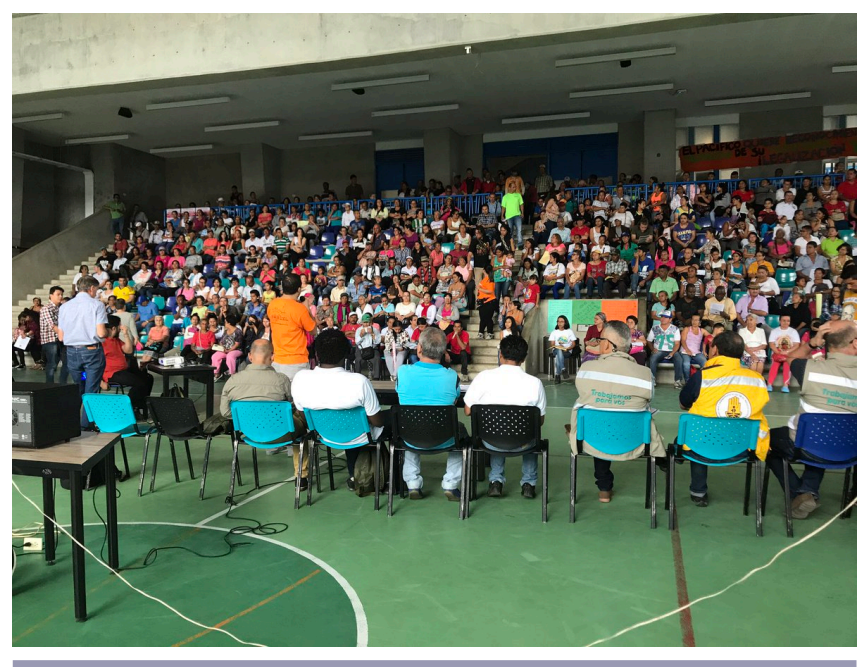

Once the monitoring and mitigation action-research activities had been completed in Pinares, three workshops were undertaken during early October 2017:

- An evaluation workshop with the community-based monitoring team, volunteer community self-builders, and community leaders, to evaluate the community-based monitoring and mitigation;

- A multistakeholder workshop involving community members and representatives from key relevant public administration organizations involved in the district, which was held in the community hall by Pinares;

- A multistakeholder workshop involving community members and representatives from key relevant NGOs working in the north-east sector of the city, which was held in a city center location to minimize travel for those attending from other districts.

The evaluation workshop with the community included a roleplay in which some of them took on the role of the key local government organizations. This helped them collectively establish their goal at the subsequent workshop with representatives from key relevant public administration organizations: to build on the experience of Pinares to develop ways of tackling risk across the city. 


\section{RESULTS AND DISCUSSION}

In relation to objective 1, the research found that the majority of the residents interviewed had known some risk in their life, including floods, landslides, and fires, but the perception of whether they currently live in a risk area as inhabitants of Pinares was more varied, from ignorance or lack of concern for the conditions of the site at the time of arrival because of other concerns, to knowledge of the risk and willingness to face the consequences. In relation to objective 2, the research demonstrated that residents in low-income neighborhoods, with appropriate technical instruction and support, are able to participate in a landslide risk monitoring system, and to collaborate with academic researchers in the collection of data that can be analyzed, as well as to implement low-cost emergency landslide risk mitigation measures. Further in-depth findings from the objective one and two research activities are presented elsewhere (Smith et al. 2020), whereas the focus of this paper is on the third objective.

For the analysis of the process of concertación generated by the project in addressing its third and final objective, we examine the dynamics found within and between each type of actor, and how these influenced the process, starting with the community. The aspects of the community evaluation most directly related to the community-based monitoring and mitigation pilot experiences are analyzed in depth elsewhere (Smith et al. 2020), but in this respect it is important to note that the preparation of the community for a process to establish pathways toward agreement with local government over landslide risk management started from the early stages of the project.

The first step in the process was the establishment of trust between the academic team and the community members who became involved. A breakthrough came in one of the early community focus groups in which community perceptions of risk were being explored. Although up to that point community members had been reticent about acknowledging risks in their neighborhood, there came a moment when they recognized the academic team's positive intent toward the community and they explicitly expressed their trust in the team, going on to talk about their fears regarding possible landslides. With one of the academic team's roles being that of facilitator, the rest of the concertación process would not have been possible without this open connection between community and the academic team being established.

The establishment of the relationship between the academic team and the community members was facilitated by two things: previous engagement of academics from the Universidad de Colombia with vulnerable communities in the area, and the fact that one of the academic team members was a community leader at district level in Comuna 8, with strong existing links with the key community leader in Pinares de Oriente. The influence that this team member/community leader had on the project on account of his links with the residents was significant. It meant the research team had immediate access to both understanding and interacting with the participatory surround that Abbott (1996) claims is fundamental for appropriate public participation. Importantly also, the community leaders in Comuna 8, including Pinares de Oriente, have been developing a relationship with both local and foreign academia, with an approach based on what they call a "dialogue of knowledges" (diálogo de saberes). An ever more savvy community leadership not only increasingly includes people with university education and other training, but is also more actively seeking engagement with academia, in whom they see both a source of knowledge and an ally in helping the community interpret technical studies commissioned by the local government.

This provided a fertile environment for the establishment of the iterativity proposed by Lemos and Morehouse (2005) in order to achieve science-policy coproduction, which they contend involves three essential components: stakeholder interaction, usable science, and interdisciplinarity. In this case, stakeholder interaction had been built into the process from the formulation of the project, in which the research team member who was a community leader had taken an active role, and continued throughout the project via regular community/research team meetings. Usable science, i.e., "knowledge that meets constituent needs" (Lemos and Morehouse 2005:61), was a key component of objective 2. And interdisciplinarity was taken a step further by the project toward transdisciplinarity, which acknowledges the superposition of realities and tries to confront them, focusing on complexity (Smith and Jenkins 2015). This approach (1) tackles complexity in science and knowledge fragmentation; (2) accepts local context and uncertainty, thus becoming a context-specific negotiation of knowledge; (3) implies intercommunicative action, with continuous collaboration between research and practice; and (4) is action-oriented (Lawrence and Després 2004).

The trust enabled by this intercommunicative action further helped the interactions between the academic team and community volunteers in the process of establishing the community-based monitoring system and mitigation pilots. Here it became obvious that the process of concertación needed to start within the community. The process of identifying key points to monitor and of agreeing who would do so, already required community volunteers to understand the criteria for monitoring point selection, and on this basis help identify points using their local knowledge. Although much of the point identification was driven by the geotechnical experts in the academic team, the participatory mapping with volunteer community researchers involved the prioritization of monitoring points and recognizing their significance in relation to hazards.

The importance of this intra-community process became more prominent when it came to identifying and prioritizing mitigation works. Tackling water drainage through the neighborhood, the academic team developed a set of clear criteria to define a hierarchy of spaces and networks, the overall principle being that of community rather than individual benefit. This helped community volunteers, who were galvanized into action in larger numbers by the prospect of improvement works around their homes, to understand the decision-making rules and to engage in the decision-making process. Trust in the academic team's technical knowledge was important here, particularly in the local architect member of the team, who had extensive experience in earlier neighborhood improvement initiatives in Medellín.

The "dialogue of knowledges," which started during the collection of community perceptions of risk, therefore contributed to decision making in both the monitoring and mitigation experiences, with the research team valuing the community's knowledge of the history of the settlement, the way it is affected 
by heavy rain, etc., and the community listening to the research team's assessment of key points to monitor and mitigate proposals, as well as to its assessment of the limitations of the project. In this stakeholder interaction and intercommunicative action as described in the literature referred to above, the split between technical and community knowledge was not so clearcut, with community members raising technically very valid points when discussing proposed mitigation works, and the research team being very mindful of potentially adverse community dynamics based on previous experience.

Building on this intra-community work, the next step was to start developing the concertación process between community and local government. While the monitoring and mitigation parts of the project were being piloted, and through discussion with community members in the workshops on concertacion, the possibility of using a mechanism for interaction that had not been contemplated at the outset was identified; this was the Cabildo Abierto, described above.

The experience of the Cabildo provided valuable lessons in relation to potential mechanisms to develop a sustainable process of risk-mitigation strategy building and implementation through agreement between informal settlement communities and relevant state agencies. It was the first time in seven years that this formal arena for community-local state engagement had been used in Comuna 8 , and the first time ever it had been focused on risk mitigation. It seemed a propitious way of exploring avenues for joint risk mitigation strategy building at a district level, with separate neighborhoods having their individual say, collectively building up to a set of informed and carefully prioritized petitions to the municipality. Two aspects emerged, however, that highlighted the limitations of this mechanism. First was the fact that what was labelled as proposals in the paperwork produced by the community organizations came across as demands when presented to the local authorities, leading to confrontational interventions that nearly led to the local authority representatives leaving the assembly, despite one of the academic team members having emphasized in the initial presentations from the universities that a key rule in the process of concertación is not to close the door. A second aspect was the political use of the event that was made by some community leaders and local politicians in their interventions, as this was an ideal opportunity to perform in front of a mass of potential voters. This mechanism therefore clearly had value in bringing together the efforts of neighborhoods across the district, putting risk management on the agenda in community-municipality relations in the district, and formalizing a series of proposals and petitions, to which the local government was obliged to respond. However, it also appeared to push the key actors into traditional roles that were not necessarily conducive to agreement. Although in theory, according to its description in Colombian law, this type of governance space may appear to be deliberative in terms of Fung's (2006) mode of communication, in this particular case it combined an aggregation of demands from the different community level representations with their expression to the authorities, in a way that does not neatly fit into the categories of mode of communication identified by Fung.

Subsequent to the holding of the Cabildo, the research team, continued with the process of establishing dialogue and negotiations with local government via working meetings through which they could build up trust. The community evaluation workshop that was run at the end of the monitoring and mitigation pilots helped not only establish an overall goal for the community-local government workshop, but also to identify specific tasks that could be the focus of the negotiation with the municipality, facilitated by the universities. These ranged from construction of a box-culvert running up the main access lane through the settlement by the local government, to coordination of these actions with a wider strategy for the upper reaches of Comuna 8. The evaluation workshop also identified the relevance of the upgrading approaches that had been developed in the late 1980 s / early 1990s in response to the tragedy in Villatina.

Two key lessons drawn from the evaluation of the monitoring and mitigation pilots that were important for the process of concertación with local government are the following: first, the importance of giving proper consideration to timescales, bearing in mind what had been achieved through community self-build in a short time; and second, the low budget required, as the threat of small landslides had been reduced for approximately 30 dwellings with a budget that was equivalent to what the local government's home improvement scheme would have allocated to two homes only, thanks to the use of community self-build and avoidance of professional consultancies and administration costs. The evaluation exercise itself was valued by the participants, and as such it also helped strengthen the community's capacity to engage in dialogue around risk management, including with external bodies.

The culmination of this process came with the workshop held between community members and local government organizations. Although only EDU and ISVIMED sent representatives, the former's interest in the initiative was evident in the high number of representatives who attended (4) and in their engagement in the discussion, and the discussions with the Planning Department and DAGRD were subsequently followed up on by the community leaders and the academic research team, respectively.

Following a visit to the mitigation works in the settlement and explanation of the whole process and the pilots, the local government agency representatives praised the initiative and acknowledged that they did not have the capacity to address the risk faced by communities across the entire city. The value of the experience in Pinares was recognized, and it was acknowledged that this approach could be replicated in other neighborhoods.

EDU highlighted that from a legal perspective and therefore, for the local government, from a formal perspective too, communities such as Pinares de Oriente should not be allowed to remain on the land they occupy, defined as nonurban and as at high nonmitigatable risk. However, EDU also proposed that a solution may lie in focusing on the "meanwhile." The discussion therefore centered around what can be done via short-term solutions that increase residents' safety temporarily, while developing more permanent solutions. The discussion identified experiences in provisional water supply in other informal settlements in Medellín as an example. An important condition for EDU was, however, that the community had to be conscious of the short-term nature of such solutions, and not take these as permission to stay in the long term or as a means toward legalizing their occupation of the land. 
A key outcome of the process was the proposal, put forward by the local government agencies, to establish a Working Group (Mesa de Trabajo) with a specific agenda centered on continuing the work initiated in Pinares, which could be extended more widely in future (see Fig. 6). Specific tasks for the Working Group were agreed, many of these coming from the list developed in the preceding community evaluation workshop, and a periodicity for the meetings was established. With these decisions, a mechanism based on negotiation facilitated by the universities as an external agent had been established, with potential to develop toward an ongoing partnership approach. The Working Group started regular (though infrequent) meetings in which the mode of communication according to Fung's (2006) model combines "deliberation and negotiation" with "deploying techniques and expertise," the two "most intense" categories in Fung's scale of modes of communication and decision making. However, it should be noted that Fung's definition of "expertise" is based on "technical expertise of officials whose training and professional specialization suits them to solving particular problems" (Fung 2006:69 [emphasis in original]), whereas the "dialogue of knowledges" approach taken in the project led to different types of expertise being recognized in both community and local government participants in the Working Group. It is also worth noting that this Working Group is not a legally or formally recognized form of state/community interaction, and thus falls within the range of unofficial coproduction practices identified in the literature on service coproduction (see, e.g., Moretto 2014).

Fig. 6. Community-local government risk management Working Group established through university-led facilitation. Source: the authors.

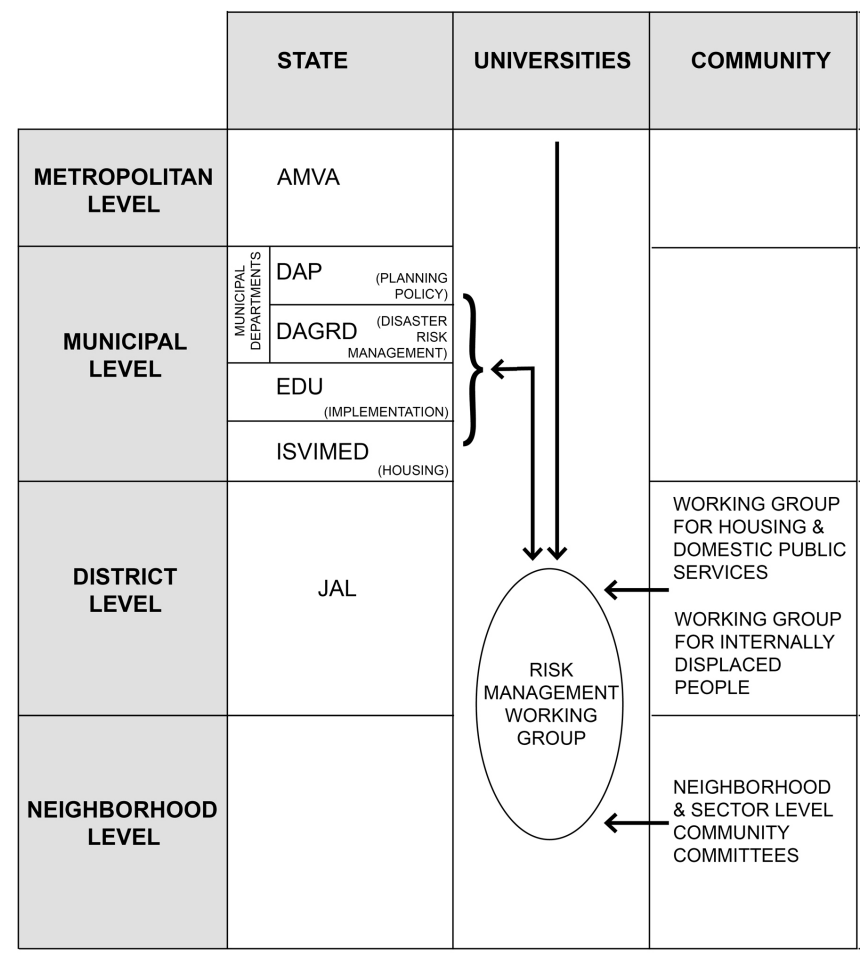

The expansion or upscaling of this state/community interaction is a challenge that we return to in the concluding section. The challenges ahead are not only about scale, as became clear in the final workshop between the community and NGOs. This workshop identified key issues to be addressed looking into the future, considering how the pilot project's success could be made sustainable in the long term. Maintaining trust between the actors, based on recognition of the community's contribution to the process, was seen as vital. Key threats to this that were identified included the different type of engagement when upscaling that could be brought about by the official position of organizations as opposed to the personal involvement of professionals to date; the potential danger of misuse of data, if monitoring data were handled directly by a local government agency (e.g., DAGRD) instead of by a mediating independent actor such as from academia; and the lack of continuity in the process if an external facilitating and/or mediating agency such as universities or NGOs were not involved. At the outset, the pilot project had aimed to facilitate the exploration of mechanisms for local governmentcommunity interaction from which the mediating academic team could withdraw in the long term. However, reflection on the process and on the capacities of the stakeholders involved highlighted the value of ongoing external involvement from either academia or the third sector.

Finally, and as an epilogue, the process also provided harsh lessons about the importance of context, particularly in a situation of conflict. From the outset the project had built in steps to mediate the existing conflict between the local state and community over land occupation and the management of disaster risk against this background. However, it did not directly engage with the nonofficial power structures that operate in the peri-urban area of Medellín, though the team was well aware of these. Land in such areas is often allocated by armed groups, who control the territory. In Pinares de Oriente, two events happened toward the end of the pilot experience that may have a bearing on how the Working Group established by the local government and community representation operates in future. First, a small plot of land was sold by an already settled household to a member of the armed group that controls land allocation in Pinares, who proceeded to excavate the hillside at precisely one of the monitoring points, going against the agreement not to interfere with land slopes that had been reached between the research team and the participating community members. Second, the armed group began selling plots of land above Pinares, an event that was seen by the community participants in the project as increasing the community's exposure to the combined hazards of flooding and landslides. These events tested the trust established within the community, as well as posing an additional challenge to the newly established Working Group.

\section{FINAL REMARKS}

The pilot project described and analyzed in this paper explored and demonstrated a way of developing a mechanism for dialogue and, eventually joint decision making, between local government and the community in managing landslide risk in informal settlements. It was found that such joint decision making is considered important but difficult to achieve, not only between community and other stakeholders, but also within each actor because they are not monolithic. Different agendas had to be accommodated, and external facilitation (in this case from the 
academic team) was required to help the stakeholders involved develop innovative platforms for dialogue. The process included the use of an established (though seldom used) form of engagement between government and civil society in Colombia, the Cabildo Abierto, which was found not to be necessarily conducive to a collaborative approach. The latter was more easily fostered through the sharing of the pilot project experience in monitoring and mitigation via nonconfrontational workshops, as well as meetings with the individual local government organizations involved.

In particular, this approach allowed a key point of confrontation between community and local government to be surmounted: the residents' right to remain in their informal settlement. Reorienting the problem away from conventional long-term land use planning issues toward issues of safety helped establish a joint local government-community Working Group, on the basis that they are addressing the immediate risks faced by informal settlement residents "in the meantime." This, together with an incremental approach based on starting with specific tasks linked to the pilot community, opened up opportunities to develop wider negotiated mitigation of landslide risk at a more strategic level.

The process started off with a form of conciliation, with the academic research team initiating the pilot projects together with the community organizations in Pinares while simultaneously introducing these projects to relevant public administration bodies. Using the results of the pilot projects as a basis, it then moved on to a form of negotiation through the multistakeholder workshop involving community members and representatives from key relevant public administration organizations, again with the universities as mediators. The next stage is based on consensusbuilding, through the Working Group that has been established by the local government agencies and community groups, with the universities no longer facilitating, but becoming an observer to learn from this process for future initiatives.

The success in using mechanisms for interaction that have not relied on the established formal means of communication between community and state (except in the case of the Cabildo) suggests that there are similarities with public service coproduction processes that have been analyzed elsewhere, which often rely on unofficial mechanisms. There is therefore scope to learn from these for the development of more community-based disaster risk management strategies and mechanisms. Conversely, the work presented here raises issues for further research around the potential these local government/community arrangements may have for establishing a lock-in situation whereby a temporary situation becomes long-term or permanent, which have only partially been addressed in the literature on service coproduction. Moretto (2010, 2014), for example, found that the coproduction of water and sanitation services in informal settlements in Caracas, Venezuela, constituted a form of "recognition" of the right to occupy the land, although very precarious because there are no transfers of land rights. In their examination of research directions to further our understanding of coproduced water services provision, Ahlers et al. (2014) identify the need to further research the scope for institutionalization of providers and users, but not of its interaction with land use and rights, while recent debates have suggested the need to decouple land rights from service provision.
Coming back to landslide risk mitigation, applying Fung's (2006) democracy cube to risk management coproduction enables the development of a systematic understanding from the perspective of public participation. For example, in this project there were two different types of governance space, the "Open Cabildo" and the "Working Group" (Table 1). The participant selection for the Cabildo was open to the entire community whereas community participants in the Working Group were self-selected, through a mediated process involving the JAC and the project activities.

The Cabildo was a large assembly of community members and the dialogue was orientated toward presentation of ideas and petitions from community groups and a response from the institutional actors wherein the residents were asking for institutional accountability. However, it does not neatly fit Fung's classification of modes of communication and decision because it combined a series of elements including (1) "expressing preferences," which local government officials were obliged not only to listen to and consider in their own subsequent deliberations, but also to respond to, (2) previous "aggregation and bargaining" among the residents and community leaders within each of the 33 communities that presented their demands, as well as among community leaders to present a district-level agenda for negotiation, further "aggregation" (though not "bargaining") at the Cabildo itself, and indeed (3) a certain degree of "negotiation" (rather than "deliberation and negotiation") between the district-level community leaders and local government officials regarding how the agenda would be taken forward. On the other hand, the Working Group was focused on negotiation and deploying the expert knowledge from both sides (involving not only technical expertise), and thus opening up a space for negotiation around the allocation of resources and devising of coproduced strategies for risk mitigation (see Smith 2003).

In terms of the sphere of influence, the Open Cabildo was called to address district-wide issues with involvement from community organizations from across the entire district whereas the Working Group was set up to deal with issues specific to the small community of Pinares. This results in a very different extent of influence for both governance spaces. On the one hand the Working Group was used as an opportunity for the residents to gain language, knowledge, and techniques for a model of cogovernance with the local authorities. On the other hand, the Cabildo Abierto was more confrontational and seen as an opportunity for the residents to gain advice and/or seek explanations from the institutional actors. What became apparent is that the Working Group facilitated coproduction that ensures action is taken forward by other actors (including the community itself).

Working with these governance spaces in Pinares de Oriente helped the research team address what Maskrey (2011) had anticipated was a major paradigm shift, as vulnerable communities changed roles from objects to subjects. The shift that is recorded in this paper has shown that informal arrangement of powers can be equally, if not more, important in bridging the gap between vulnerable communities and institutional actors to unlock "political and economic resources required to manage risks" (Maskrey 2011:44). It also highlights a limitation in Fung's democratic cube in that it appears to be focused on formal powers 
around public participation, which limits its explanatory power when it comes to analyzing coproduction experiences such as this project. This suggests the need to further develop the democratic cube to take into account more informal and unofficial governance processes, which are particularly relevant in the Global South.

However, the sustainability and upscaling of collaborative riskmitigation strategy building and implementation experimented with in Medellín also faces challenges. These include maintaining a balance between the interests of communities and local government organizations; managing the turnover in communities (with the consequent loss in knowledge and engagement) and in state organizations (particularly linked to political cycles); keeping the levels of trust between community representatives and local government officials because upscaling may lead to more formalization of the mechanisms for concertación; and last but not least, addressing the issues raised by de facto control of peri-urban land by armed groups.

Responses to this article can be read online at: http://www.ecologyandsociety.org/issues/responses. $\mathrm{php} / 11337$

\section{Acknowledgments:}

This research was funded by the United Kingdom's Global Challenges Research Fund "Building Resilience" programme, led by the Natural Environment Research Council (NERC), the Arts and Humanities Research Council (AHRC), and the Economic and Social Research Council (ESRC) (Project no. NE/P015557/1). The authors wish to thank all the community researchers in Pinares de Oriente, Medellin, for their engagement in this research, without which it would not have been possible. The authors also wish to thank Dr Liz Holcombe, at the University of Bristol, for her valuable comments on an early draft of this paper, and the anonymous reviewers of the paper, whose comments helped strengthen its contribution to the literature.

\section{LITERATURE CITED}

Abbott, J. 1996. Sharing the city: community participation in urban management. Taylor and Francis, London, UK. https://doi. org/10.4324/9781315070759

Ahlers, R., F. Cleaver, M. Rusca, and K. Schwartz. 2014. Informal space in the urban waterscape: disaggregation and co-production of water services. Water Alternatives 7(1):1-14.

Alcaldía de Medellín. 2005. Moravia: memorias de un puerto urbano. Programa de Memoria y Patrimonio Cultural, Proyecto de Memoria Cultural Barrio Moravia, Medellín, Colombia.

Alcaldía de Medellín. 2014. Acuerdo 48 de 2014 "Por medio del cual se adopta la revisión y ajuste de largo plazo del Plan de Ordenamiento Territorial del Municipio de Medellín y se dictan otras disposiciones complementarias". Publicado el 17 de diciembre en la Gaceta Oficial 4267 de 2014. Alcaldía de Medellín, Medellín, Colombia. [online] URL: https://www.medellin.gov.co/irj/go/km/
docs/pccdesign/SubportaldelCiudadano 2/PlandeDesarrollo 0 17/ ProgramasyProyectos/Shared $\% 20$ Content/Documentos/2014/POT/ ACUERDO \%20POT-19-12-2014.pdf

Allen, A., J. Davila, and P. Hofman. 2006. Governance of water and sanitation services for the peri-urban poor: a framework for understanding and Action in Metropolitan Regions. Development Planning Unity, University College London, London, UK.

Alvarado Beltrán, A. M. 2014. La participación ciudadana en la República de Colombia. El Cabildo Abierto. Dissertation. Universidad Nacional de Educación a Distancia, Madrid, Spain.

Anderson, M. G., and E. A. Holcombe. 2013. Community-based landslide risk reduction: managing disasters in small steps. World Bank, Washington, D.C., USA. https://doi.org/10.1596/978-0-8213-9456-4

Anderson, M. G., L. Holcombe, D. Williams. 2007. Reducing landslide risk in areas of unplanned housing in the Caribbeana Government-Community partnership model. Journal of International Development 19:205-221. https://doi.org/10.1002/ jid.1336

Aristizábal, E., and J. Gómez. 2007. Inventario de emergencias y desastres en el Valle de Aburrá. Originados por fenómenos naturales y antrópicos en el periodo de 1880-2007. Revista Gestión y Ambiente 10(2):17-30.

Arnstein, S. R. 1969. A ladder of citizen participation. Journal of the American Institute of Planners 35(4):216-224. https://doi. org/10.1080/01944366908977225

Batley, R., and C. Mcloughlin. 2010. Engagement with non-state service providers in fragile states: reconciling state-building and service delivery. Development Policy Review 28(2):131-154. https:// doi.org/10.1111/j.1467-7679.2010.00478.x

Blaikie, P., and T. Cannon. 1996. Vulnerabilidad, el entorno social, político y económico de los desastres. Red de Estudios Sociales en Prevención de Desastres en América Latina, Bogotá, Colombia.

Brooks, R. W. S., and G. R. Harris. 2008. Citizen participation, NEPA, and land-use planning in northern New York, USA. Environmental Practice 10(4):140-151. https://doi.org/10.1017/ $\underline{\mathrm{S} 1466046608080356}$

Carpentier, N. 2016. Beyond the ladder of participation: an analytical toolkit for the critical analysis of participatory media processes. Javnost - The Public 23(1):70-88. https://doi. org/10.1080/13183222.2016.1149760

Chardón, A. 1997. La percepción del riesgo y los factores socioculturales de vulnerabilidad. Caso de la ciudad de Manizales, Colombia. Desastre y Sociedad 8:1-34.

Coupé, F., E. Arboleda, and C. García. 2007. Villatina: Algunas reflexiones 20 años después de la tragedia. Gestión y Ambiente 10 (2):31-52.

Empresa de Desarrollo Urbano and SIGA Ingeniería y Consultoría S.A. sucursal Colombia (EDU and SIGA S.A.) 2015. Estudios de amenaza, vulnerabilidad y riesgo de detalle para los polígonos de barrios sostenibles en el municipio de Medellín. Convenio Marco 47930 de 2013 de la Secretaria de Infraestructura Física. EDU and SIGA, Medellín, Colombia. 
Filardi, F. A. 2008. Identifying housing conditions in Bogotá, Colombia: a strategy to deal with risks. Pages 105-118 in $\mathrm{T}$. Kidokoro, J. Okata, S. Matsumara, and S. Shima, editors. Vulnerable cities: realities, innovations and strategies. Springer, Tokyo, Japan. https://doi.org/10.1007/978-4-431-78149-3 5

Fung, A. 2006. Varieties of participation in complex governance. Public Administration Review 66(1):66-75. https://doi.org/10.1111/ j.1540-6210.2006.00667.x

Fung, A. 2012. Continuous institutional innovation and the pragmatic conception of democracy. Polity 44(4):609-624. https:// doi.org/10.1057/pol.2012.17

Grindle, M. S. 1996. Challenging the state: crisis and innovation in Latin America and Africa. Cambridge University Press, Cambridge, UK. https://doi.org/10.1017/CBO9780511521829

Jenkins, P., and H. Smith. 2001. An institutional approach to analysis of state capacity in housing systems in the developing world: case studies in South Africa and Costa Rica. Housing Studies 16(4):485-507. https://doi.org/10.1080/02673030120066563

Lawrence, R. J., and C. Després. 2004. Introduction: futures of transdisciplinarity. Futures 36:397-405. https://doi.org/10.1016/j. futures.2003.10.005

Lemos, M. C., and B. J. Morehouse. 2005. The co-production of science and policy in integrated climate assessments. Global Environmental Change 15:57-68. https://doi.org/10.1016/j. gloenvcha.2004.09.004

Maskrey, A. 2011. Revisiting community-based disaster risk management. Environmental Hazards 10(1):42-52. https://doi. org/10.3763/ehaz.2011.0005

Moretto, L. 2010. Coproduction du service d'eau et recomposition de l'espace intra urbain dans la périphérie Sud de Caracas. Espaces et sociétés 3(143):81-99 https://doi.org/10.3917/ esp. 143.0081

Moretto, L. 2014. Assessing urban governance: the case of water service co-production in Venezuela. PIE Peter Lang, Brussels, Belgium.

Muñoz Duque, L. 2014. Apego al lugar y percepción del riesgo en población expuesta a inundación: un estudio comparativo. Thesis. Universidad de Antioquia, Medellín, Colombia.

Nadim, F., and S. Lacasse. 2008. Landslide risk assessment and mitigation strategy. Pages 31-61 in K. Sassa and P. Canuti, editors. Landslides-disaster risk reduction. Springer, Berlin, Germany. https://doi.org/10.1007/978-3-540-69970-5 3

Neekhra, V. 2008. Growing vulnerability crisis "will slums ever reduce or improve?": a case from India. Pages 77-103 in $\mathrm{T}$. Kidokoro, J. Okata, S. Matsumara, and S. Shima, editors. Vulnerable cities: realities, innovations and strategies. Springer, Tokyo, Japan. https://doi.org/10.1007/978-4-431-78149-3 4

Olivier de Sardan, J. P. 2011. The eight modes of local governance in West Africa. IDS Bulletin 42(2):22-31. https://doi.org/10.1111/ j.1759-5436.2011.00208.x

Phumpiu, P., and J. E. Gustaffsson. 2009. When are partnerships a viable tool for development? Institutions and partnerships for water and sanitation service in Latin America. Water Resources Management 23:19-38. https://doi.org/10.1007/s11269-008-9262-8
Rahman, T. 2012. Landslide risk reduction of the informal foothill settlements of Chittagong City through strategic design measure. Thesis. BRAC University, Dhaka, Bangladesh.

Rivera, J. 2010. La comunicación del riesgo, hacia un modelo efectivo $y$ situacional. Instituto Tecnológico Metropolitano, Medellín, Colombia.

Ruesga, G., and B. Knight. 2013. The view from the heights of Arnstein's ladder: resident engagement by community foundations. National Civic Review 102(3):13-16. https://doi. org/10.1002/ncr.21137

Sánchez, L., and A. Gutiérrez. 2014. Potencialidades de la participación en la construcción de ciudad desde intervenciones urbanas en asentamientos precarios. Revista América Latina Hoy 68:119-136. https://doi.org/10.14201/alh201468119136

Smith, H. 2003. Spaces of negotiation in low-income housing in San José, Costa Rica. International Development Planning Review 25(2):169-193. https://doi.org/10.3828/idpr.25.2.4

Smith, H., S. Garcia-Ferrari, G. Medero, H. Rivera, F. Coupé, H. Caballero, W. Castro, A. Abiko, F. A. M. Marinho, and K. Ferreira. 2020. Learning from co-produced landslide risk mitigation strategies in low-income settlements in Medellín (Colombia) and São Paulo (Brazil). Chapter 10 in A. Ley, A. U. Rahman, and J. Fokdal, editors. Housing and human settlements in a world of change. Transcript, Bielefeld, Germany.

Smith, H., and P. Jenkins. 2015. Trans-disciplinary research and strategic urban expansion planning in a context of weak institutional capacity: case study of Huambo, Angola. Habitat International 46:244-251. https://doi.org/10.1016/j.habitatint.2014.10.006

Toro, M., L. Mejía, G. Bedoya, and M. Hermelin. 2009. Red comunitaria para la gestión ambiental en el Valle de Aburrá. Gestión y Ambiente 13(1):67-76.

UN-Habitat. 2003. The challenge of slums. United Nations Human Settlements Programme, Nairobi, Kenya.

UN-Habitat. 2015. United Nations conference on housing and sustainable development: issue paper on informal settlements. United Nations Human Settlements Programme, Nairobi, Kenya.

Unidad Nacional para la Gestión del Riesgo en Colombia (UNGRD). 2013. Guia Municipal para la Gestión del Riesgo de Desastres. Banco Mundial, Bogotá DC, Colombia.

United Nations / International Strategy for Disaster Reduction (UN/ISDR). 2004. Living with risk: a global review of disaster reduction initiatives. United Nations Office for Disaster Risk Reduction, Geneva, Switzerland.

URBAM and Harvard Design School. 2012. Re Habitar La Ladera: shifting ground. Universidad EAFIT, Medellín, Colombia.

Wamsler, C. 2007. Managing urban disaster risk. Dissertation. Lund University, Lund, Sweden.

Wild, L., V. Chambers, M. King, and D. Harris. 2012. Common constraints and incentive problems in service delivery. Working Paper 351. Overseas Development Institute, London, UK. 